$\left(\begin{array}{llr}\text { J.Soc.Cosmet.Chem.Jpn. } \\ \text { 報 } \\ 30(1) & 94-\quad 103(1996)\end{array}\right)$

位置ずれ，回転ずれをおこしているしわの 3 次元形状のパターンマッチング†

\author{
金子 治 $\dagger^{2}$ ，和気雅美$\dagger^{2} ， 川 口 由$ 起子 $\dagger^{2}$ ，小松原良平 $\dagger^{3}$ \\ 株式会社資生堂 ビューティーサイエンス研究所共 \\ 有限会社テクノアーツ研究所や豆
}

\begin{abstract}
著者らは, 生体のしわの 3 次元形状を非接触で瞬時に計測できる装置を開発し, 一過性で発生した しわの形状変化や，抗しわ剤を連用した時のしわの形状変化を計測している。この場合，異なる時点で 計測した計測対象領域間の幾何学的位置が正確に照合できなければ，時間経過後の形状変化をデー夕化 することは不可能である。一般に，時間をおいて同一人のしわ形状を計測した場合，どのように注意し て計測しても同一計測領域を測定することは困難で，結果として位置ずれが生じる。位置ずれには，観 測系に対して計測領域が X,Y 方向にずれるケース，回転ずれを起こすケース，両者が同時に起こるケ 一ス，並びに，観測対象そのものが管理しえない要因によって変形することで生じる拡大・縮小，局所 的なひずみに起因するケースなどが考えられる。しわの場合, 計測領域内に複数の位置のマーカーが定 義できないので，計測領域全体を対象にした拡大・縮小ならびにひずみの補正は困難である。

著者らは位置合わせ領域を，比較・照合したいしわを含む小領域に限定することにより，計測領域の 回転ずれの補正と X,Y 方向のずれの補正に関して妥当性の高い方法を見いだした。また，計測時期の 異なるデータに見られるしわの形状変化を比較・照合する新たな方法を考案したので報告する。
\end{abstract}

\section{1. 緒言}

著者らは, 生体のしわの 3 次元形状を非接触 で瞬時に計測できる装置を開発〉し，一過性で発 生したしわの形状変化や，抗しわ剂を連用した時 のしわの形状変化を計測している。この場合, 異 なる時点で計測した計測対象領域間の幾何学的位 置が正確に照合できなければ，時間経過後の形状 変化をデー夕化することは不可能である。一般 に，時間をおいて同一人のしわ形状を測定した場 合，どのように注意して計測しても同一計測領域 を測定することは困難で, 結果として位置ずれが 生じる。位置ずれには，観測系に対して計測領域 が X,Y 方向にずれるケース，回転ずれを起こす ケース，両者が同時に起こるケース，並びに，観

\footnotetext{
† 1995.9.22 受理

$\dagger^{2}$ ₹141 東京都品川区西五反田 3-9-1；3-9-1 Nishigotanda, Shinagawa-ku, Tokyo 141 Japan

$\dagger^{3}$ 个183 東京都府中市寿町3-10-7;3-10-7 Kotobuki -cho, Fucyu, Tokyo 183 Japan
}

測対象そのものが管理しえない要因によって変形 することで生じる拡大・縮小，局所的なひずみに 起因するケースなどが考えられる。しわの場合, 計測領域内に複数の位置のマーカーが定義できな いので，計測領域全体を対象にした拡大・縮小な らびにひずみの補正は困難である。

著者らは位置合わせ領域を，比較・照合したい しわを含む小領域に限定することにより，計測領 域の回転ずれの補正と X,Y 方向のずれの補正に 関して妥当性の高い方法を見いだした。また，計 測時期の異なるデー夕に見られるしわの形状変化 を比較・照合する新たな方法を考案したので報告 する。

\section{2. 方法}

形が複雑な 2 つ0 3 次元形状物体が 3 次元空 間内で位置ずれを起こして存在している場合, $\mathrm{X}, \mathrm{Y}, \mathrm{Z}$ の方向別に, 相互の位置ずれ量を求め, 仮想空間内で一例えば，コンピュータ内で一重ね 合わせする，あるいは重ね合わせができたことを 
証明する方法は，今のところ見いだされていない と思われる。一方, 2 次元の画像を対象にした位 置合わせ法については，いくつがの提案があり， 代表的な方法として, マニューシャ (端点, 分岐 点の位置と方向, 即ち, 線要素) を手がかりとし た X,Y 方向の補正方法) (対象図形はほぼ相似 形。回転はしていない。拡大・縮尺率は, 既知) や，テンプレートマッチング法3) (対象図形は, 相似形。回転はしていない)，あるいはポイント ・マーカーを手かがりとした回転・拡大・縮小の 補正方法)(ひずみの補正は，不可）などがある。

しかしながら，しわの場合，時間の経過ととも にしわ形状の局部的消失や，新たなしわの発生が あり, マニューシャとしての端点の位置情報, 線 の分岐点の位置とその方向といった情報が使えな いし，比較する画像が相似形で回転していないと いう条件を満たしていないことからテンプレート マッチング法も適用できない。また, 不変な位置 のポイント・マーカーとしての複数の点や線分も 定義することができないことから，これらを手が かりとした方法も利用できない。そこで, 観測系 からみた計測対象領域の回転方向のずれ（同一人 の目尻のしわを $\mathrm{t}_{1}, \mathrm{t}_{2}$ 時点で計測した 3 次元形状 計測デー夕がある時, $\mathrm{t}_{2}$ 時点のデー夕から構成し たしわ画像の $\mathrm{t}_{1}$ 時点のしわ画像に対する回転角 度）を，当該しわ画像の 2 次元離散的フーリエ 变換後の空間周波数成分の付置情報から推定し, 回転ずれを補正すると共に，得られた回転ずれを 補正した $t_{1}, t_{2}$ 時点のしわ画像の関心領域（しわ の変化の様子が知りたい部位) を対象にしたテン プレートマッチングを行い, X, Y 方向のずれを 補正することを試みた。

\section{1 回転ずれの補正}

著者らは, 目尻のしわの3 次元形状計測值に のっている被験者個々の骨格・肉付き形状を高次 回帰式を用いて推定し, 除去することによって, しわの深さのみの情報から構成される 2 次元の 『しわマップ』の作成方法を提案1)している。こ の『しわマップ』は, 縦横 $12.5 \mathrm{~mm} \times 15 \mathrm{mmmm}$ 相 当の領域を $128 \times 128$ に分割した時の, 個々の格 子点におけるしわの深さの計測デー夕から構成さ
れている。ここでは,この2 次元の『しわマッ プ』を対象に， $t_{1}$ 時点に扔ける『しわマップ』画 像を基準にした時， $\mathrm{t}_{2}$ 時点の『しわマップ』画像 上にあらわれる，観測系に対する計測領域の回転 方向のずれを以下の方法で推定した。

任意の画素数で構成される 2 值画像に対して 2 次元離散的フーリ工変換を行って得られる2 次 元空間周波数成分の付置を，画像（図形）を回転 させながら求めてみると, その付置は, 画像の回 転量に対応する形で回転する5ことが知られてい る。2 次元離散的フーリエ変換を式(1)に示す。

$$
\begin{aligned}
& F(u, y)=\sum_{x=0}^{M-1} \sum_{x=0}^{N-1} f(x, y) \exp \left[-j 2 \pi\left(\frac{x}{M} u+\frac{y}{N} v\right)\right] \\
& \text { ここで, } \\
& f(x, y): x, y \text { に扔ける画像濃度 }(0,1) \\
& F(u, v): u, v \text { 番目の空間周波数成分 }
\end{aligned}
$$

得られた空間周波数成分の強度は, 式(2)で求め られる。

$$
\begin{aligned}
& \mathrm{P}(\mathrm{u}, \mathrm{v})=\left[\operatorname{Fre}^{2}(\mathrm{u}, \mathrm{v})+\operatorname{Fim}^{2}(\mathrm{u}, \mathrm{v})\right]^{1 / 2} \\
& \text { ここで, }
\end{aligned}
$$

Fre : u, v 番目の空間周波数成分の実数部

Fim : u, v 番目の空間周波数成分の虚数部

1 本のラインパターンの 2 值画像に対して 2 次元離散的フーリ工变換を行って求めた空間周波 数成分の付置を, Fig.-1に示す。

(c)と(d)に示した付置の長軸方向に注目すると， (d)の長軸方向は, (a)と(b)におけるラインパターン の回転に対応するかたちで反時計まわりに回転し ていることがわかる。(a)〜(d)に見られる現象は， 2 值画像が複雑な形状をとる場合でも, すべて同 様である。このことから， $\mathrm{t}_{1}$ 時点のしわ画像の空 間周波数成分の付置の長軸方向と $\mathrm{t}_{2}$ 時点のしわ 画像の空間周波数成分の付置の長軸方向を，何ら かの方法で求めることができれば，画像の回転量 が推定可能であることがわかる。『しわマップ』 を構成する計測データを, $128 \times 128$ の正方格子 点のデー夕とみなし，これを深さ $\mathrm{Z}=0$ の $256 \times$ 256 の正方格子で構成される平面に，その中心が 重なるように配置し，2次元離散的フーリエ変換 のためのデータとした。 


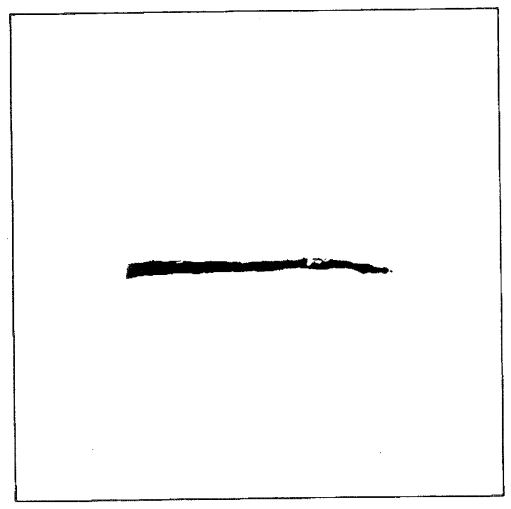

(a) Binary image of a single line pattern.

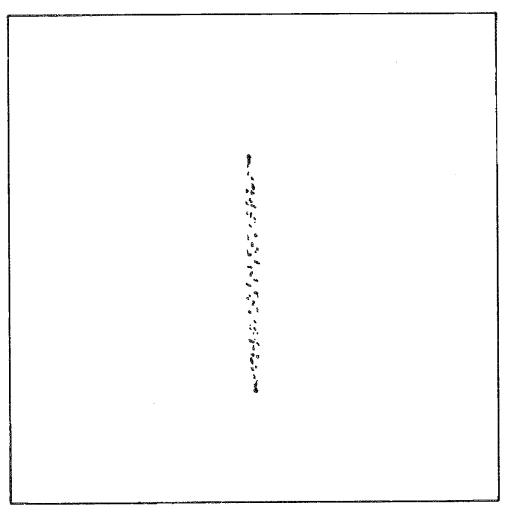

(c) Scatter diagram of spatial frequency components after two-dimensional discrete Fourier-transformation of image (a).

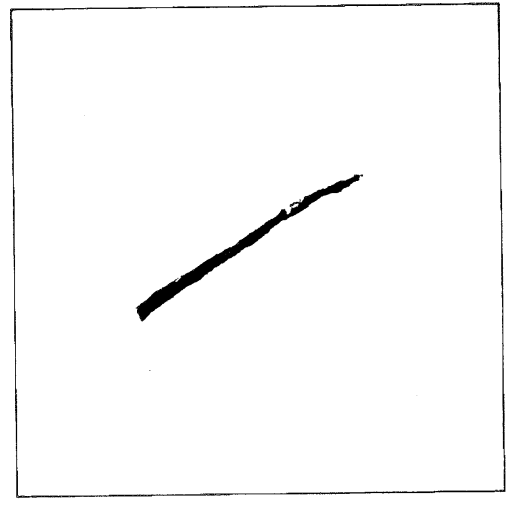

(b) Image (a) after counterclockwise rotation.

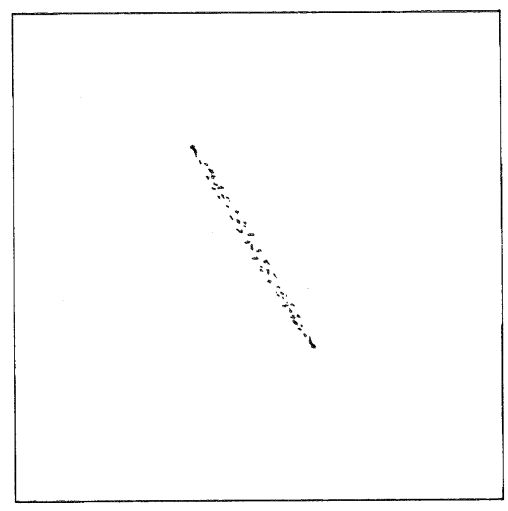

(d) Scatter diagram of spatial frequency components after two-dimensional discrete Fourier-transformation of image (b).

Fig. -1 Binary image of a single line pattern and scatter diagram of spatial frequency components after two-dimensional discrete Fourier-transformation of this image.

なお，『しわマップ』では，深さの計測值を9 分類して，即ち，9值化してしわの深さの濃淡表 示や色付け表示に利用しているが，ここでは，得 られたしわの深さに関する計測值そのものをそれ ぞれの格子点のデータとして, フーリエ変換を行 っている。ここで, $128 \times 128$ の計測データの周 辺に存在する格子点のデータを 0 としたのは, 計測データが不連続であることで扔こる空間周波 数成分の漏れを少なくするためであり，更に，ブ ラックマンウィンドウをかけ，漏れに対する対応 を厚くしている。また，空間周波数成分の付置の 構成に用いたデー夕は, 最大強度を示す空間周波
数成分から 200 番目の強度を取る空間周波数成 分まで, 計 200 個のデー夕を用いている。付置 の長軸の軸方向とX 軸がなす角 $(\theta)$ は, 以下 の式(3)〜(8)6) を使って求めた。

$$
\begin{array}{ll}
\mathrm{T}_{1}=\sum_{\mathrm{p}=1}^{\mathrm{n}} \mathrm{x}_{\mathrm{p}} & \text { (3) } \quad \mathrm{T}_{2}=\sum_{\mathrm{p}=1}^{\mathrm{n}} \mathrm{y}_{\mathrm{p}} \\
\mathrm{S}_{11}=\sum_{\mathrm{p}=1}^{\mathrm{n}} \mathrm{x}_{\mathrm{p}}{ }^{2}-\frac{\mathrm{T}_{1}^{2}}{\mathrm{n}} & \text { (5) } \quad \mathrm{S}_{22}=\sum_{\mathrm{p}=1}^{\mathrm{n}} \mathrm{y}_{\mathrm{p}}^{2}-\frac{\mathrm{T}_{2}^{2}}{\mathrm{n}} \\
\mathrm{S}_{12}=\sum_{\mathrm{p}=1}^{\mathrm{n}} \mathrm{x}_{\mathrm{p}} \mathrm{y}_{\mathrm{p}}-\frac{\mathrm{T}_{1} \mathrm{~T}_{2}}{\mathrm{n}} & \text { (7) }
\end{array}
$$


ここで,

$\mathrm{x}_{\mathrm{p}}, \mathrm{y}_{\mathrm{p}}$ : 個々の空間周波数成分の付置に対応す る座標点

$\mathrm{t}_{1}$ 時点のデータについて得られた角度 $\theta_{1}$ と $\mathrm{t}_{2}$ 時点のデー夕について得られた角度 $\theta_{2}$ の差を, 回転ずれの補正量とし，その補正量だけ， $\mathrm{t}_{2}$ 時点 の『しわマップ』を回転させた。

なお，回転ずれの大きさは，『しわマップ』全 体を対象にして，その大きさを求めるのではな く，比較・照合するしわを特定して局所的に切り 出し，そのしわを含む小領域のみを対象にしてフ 一リ工変換を行い，回転ずれの大きさを求めてい る。この操作は, $\mathrm{t}_{1}, \mathrm{t}_{2}$ 時点間に生じた, 比較. 照合するしわ以外の形状変化が，回転ずれ補正量 の算出に与える影響を除去するためにも有効な方 法である。

\section{$2.2 X, Y$ 方向のずれの補正}

著者らが開発した装置)では，光源，測定対象 物, 観測系の CCD カメラの光学的配置条件によ り, 必然的に計測領域のX (横) 方向は, 圧縮 されて画像化される。更に, 回転補正した $\mathrm{t}_{1}, \mathrm{t}_{2}$ 時点の『しわマップ』間には補正量を反映した傾 きが相互の間に生じ，正方格子の各点をそのまま 重ねることはできない。

従って，正確な位置合わせを行うためには，X， $\mathrm{Y}$ 方向のずれの補正を行う前に, $\mathrm{t}_{1}$ 時点で計測し たデータで作成した『しわマップ』の格子点間で 表現される形状物上の距離と， $\mathrm{t}_{2}$ 時点で計測した データで作成した『しわマップ』の格子点間で表 現される形状物上の距離を一致させるとともに, 正方格子の傾きに差がない新たな座標点の再構築 と, その点の 3 次元計測デー夕の算出が必要と され，この処理を行っている。

また，通常，縦横 $12.5 \mathrm{~mm} \times 15 \mathrm{~mm}$ 相当の計 測領域について, $128 \times 128$ の 3 次元座標值が得 られるが，回転ずれや，X,Y 方向のずれが生じ ている場合， $t_{1}$ 時点の計測領域と $t_{2}$ 時点の計測 領域に重なりが見られない部分が発生するので, 領域全体を比較・照合の領域とすることは不可能 である。ここでは，まず $\mathrm{t}_{1}$ 時点で得られた『し わマップ』データをもとにして, 座標点 $(64,64)$
を中心にした縦横 $80 \mu \mathrm{m}$ 間隔， $128 \times 128$ の正方 格子の格子点の 3 次元形状計測值を計算によっ て求めた。次いで，回転ずれを補正した $\mathrm{t}_{2}$ 時点 のデータで構成した『しわマップ』についても同 様の演算処理を行なった。

結果として, $\mathrm{t}_{1}, \mathrm{t}_{2}$ 時点の計測領域の中心部分, $10240 \mu \mathrm{m} \times 10240 \mu \mathrm{m}$ の領域を $80 \mu \mathrm{m}$ 間隔， 128 $\times 128$ 座標点で再構成したことになる。(この作 業を等ピッチ化と呼ぶことにする)。

このように再構成した $\mathrm{t}_{1}, \mathrm{t}_{2}$ 時点のデー夕は， 回転ずれの補正と等ピッチ化は終了しているが,

$\mathrm{X} ， \mathrm{Y}$ 万向の補正は行なわれていない。そこで上 記した手続きで求めた $\mathrm{t}_{1}$ 時点の， $128 \times 128$ 座標 点からなる等ピッチ化後の『しわマップ』上で, 比較したいしわを含む小領域（矩形領域）を指定 し，これをテンプレートとする。このテンプレー 卜を，回転ずれを補正した $\mathrm{t}_{2}$ 時点のデー夕から 構成した等ピッチ化後の『しわマップ』上の左上 から，右方向に走査させ，重㸚わさった小領域 内，各座標点の深さデー夕を対のデータとした時 の相関係数を，逐次，算出した。

そして, 最も 1 に近い正の相関が得られた位 置を，マッチングが取れた位置とし，その時のテ ンプレートの座標点位置から，X，Y 方向のずれ の大きさを求め， $\mathrm{X} ， \mathrm{Y}$ 方向の補正を行った。

Fig.-2に，上記した位置合わせの作業フローを 示す。

\section{3 位置合わせ終了後のデータの比較}

上記した手続きによって，回転ずれ，X，Y方 向のずれの補正は完了したことになる。 $\mathrm{t}_{1}, \mathrm{t}_{2}$ 時 点のしわ形状データの比較は,

(1)『しわマップ』を用いた $t_{1} ， t_{2}$ 時点のしわ 形状の同時ビジュアル表示。

(2) 比較・照合領域内の任意の断面に扔ける $\mathrm{t}_{1}, \mathrm{t}_{2}$ 時点の梁さデー夕曲線の重亦書き表示 とその差の数值表示。

(3) 比較・照合領域内のしわの平均深さとその 標準偏差。

などを用いて行っている。なお，計測領域全体の 3 次元形状変化については，先に報告した1)しわ の深さのパラメータ，しわの数とサイズに関する 


\begin{tabular}{|c|}
$\begin{array}{c}3 \text {-dimensional measurement of } \\
\text { wrinkles at time } t_{1}\end{array}$ \\
\hline Calculation of "wrinkle map" \\
\hline Positioning : designate wrinkle \\
\hline Fourier-transformation \\
Calculation of angle \\
\hline
\end{tabular}

3.

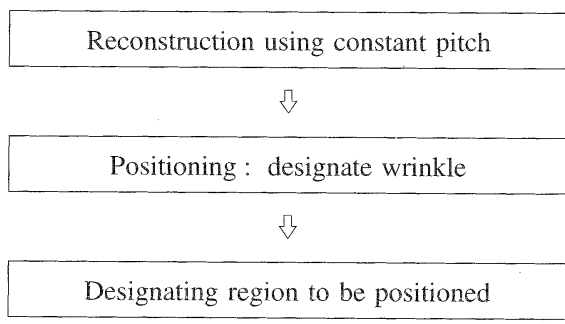

Designating region to be positioned

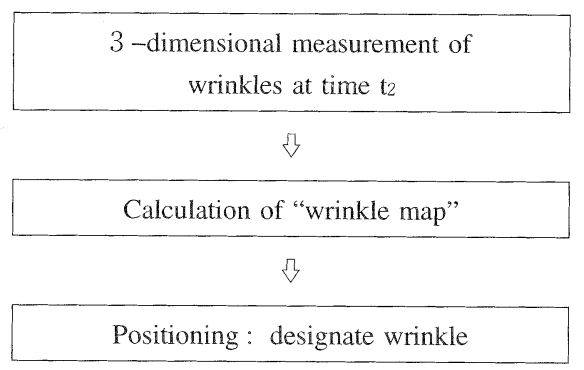

8

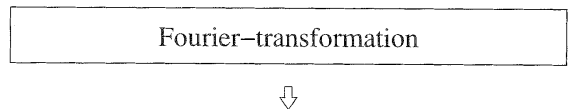

ת

Calculation of angle

$\sqrt{3}$

Caluculation of angle difference

子y

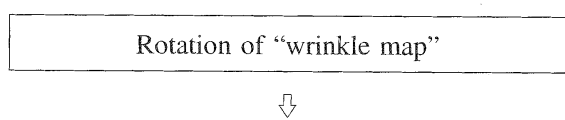

ת

Reconstruction using constant pitch

$\sqrt{2}$

Positioning : designate wrinkle

\)

$\Rightarrow$

Template matching

8

Correction of dislocation along

$\mathrm{X}$-and/or Y-axes

$\sqrt{3}$

Expression of changes in wrinkle morphology

Fig.-2 Flow-chart of positioning procedure.

パラメータを求め, 比較している。

\section{3. 害施 例}

Fig.-2の作業フローにしたがって，位置合わ せを行った例を以下に示す。ここでは同一レプレ 力を用いて，意識的に回転ずれと X,Y 方向のず
れをおこしたデー夕を作成し，実施例のデー夕と している。これによって拡大・縮小・局部的ひず みのないケースに扮ける位置合わせの精度をみる ことができる。

Fig.-3に, 目尻のしわレプリカの 3 次元形状 計測データから作成した『しわマップ』（これを， 
$\mathrm{t}_{1}$ 時点での測定データの事例とする）を Fig.-3 に，そのレプリカを時計回りに約 5 度回転させ, 更にX，Y 方向にずらして計測したデータから 作成した『しわマップ』(これを， $\mathrm{t}_{2}$ 時点での測

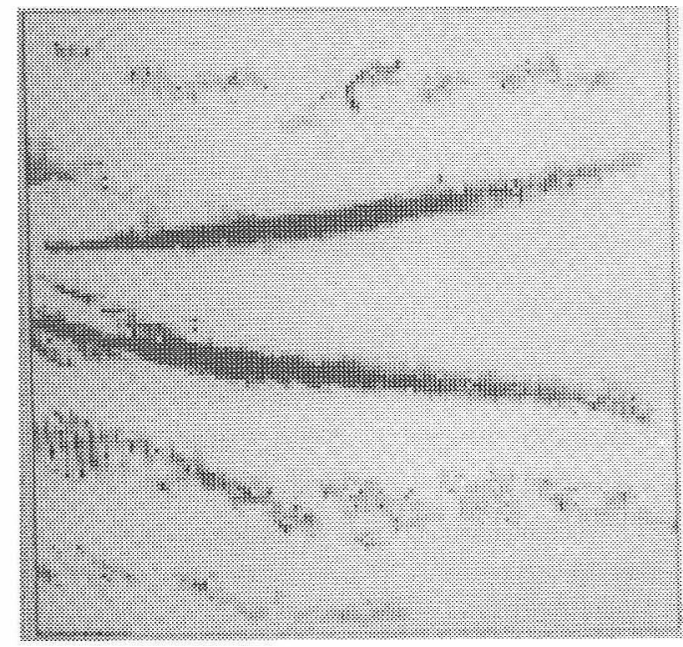

Fig. -3 Example of data obtained at time $t_{1}$.

"Wrinkle map"constructed using results from threedimensional measurement of a wrinkle replica.

定データの事例とする）を Fig.-4 に示す。Fig.-

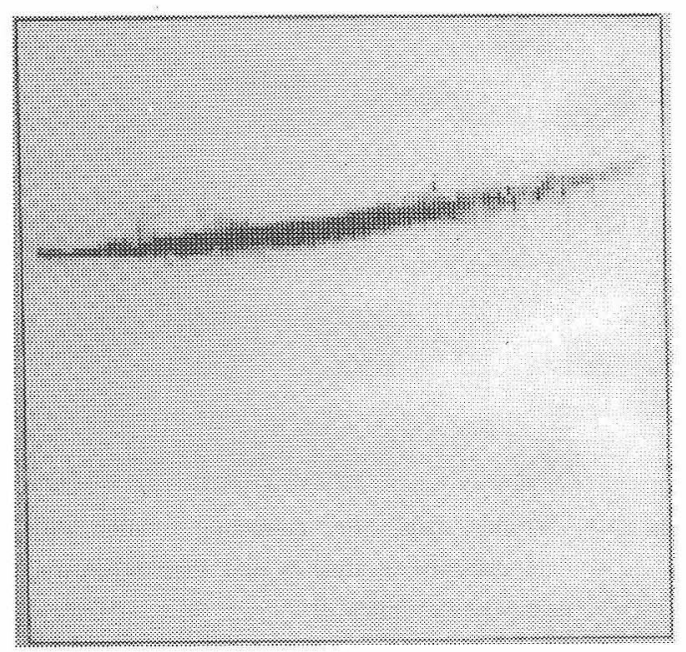

Fig. -5 Wrinkle isolated from Fig. -3 .

3 と Fig.-4にみられるパターンの微妙な違い は，本計測システム由来のものである。
Fig.-5, Fig.-6に，比較対象とするしわの切り 抜き結果を示吋。

Fig.-5, Fig.-6のデータに対して, フーリエ変

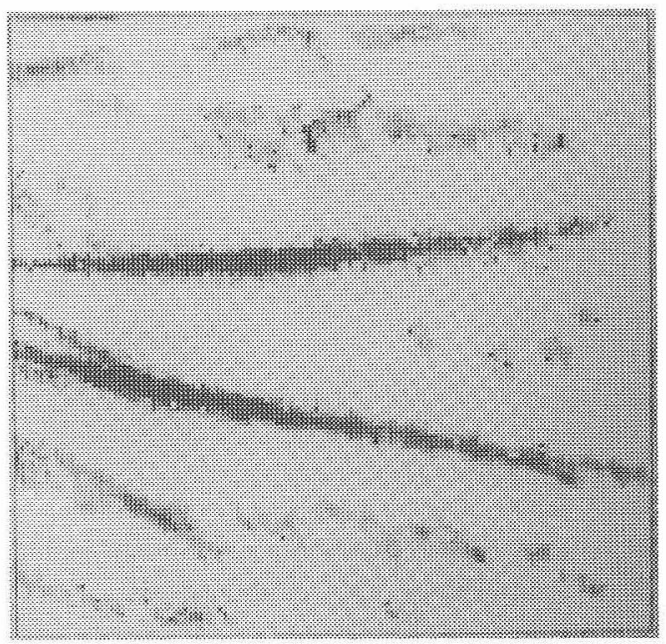

Fig. -4 Example of data obtained at time $t_{2}$.

"Wrinkle map"constructed using the results from the measurement after the same wrinkle replica was rotated 5 degrees clockwise and then shifted along both $\mathrm{X}$-and $\mathrm{Y}$-directions.

換を行って得られた空間周波数成分の付置と, 算

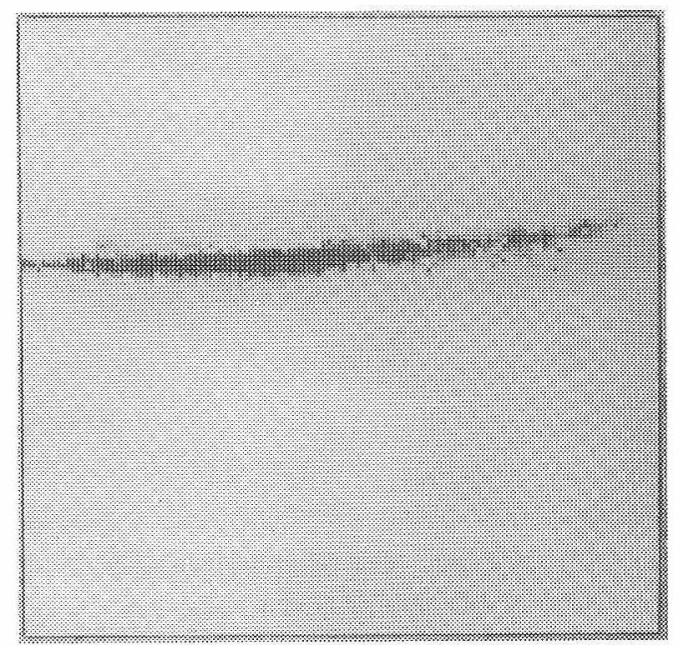

Fig.-6 Wrinkle isolated from Fig. -4 .

出された長軸方向とその傾き角 $\left(\theta_{1}, \theta_{2}\right)$ を Fig. -7 , Fig. -8 に示す。

結果として，4.6度の回転ずれがおきているこ 


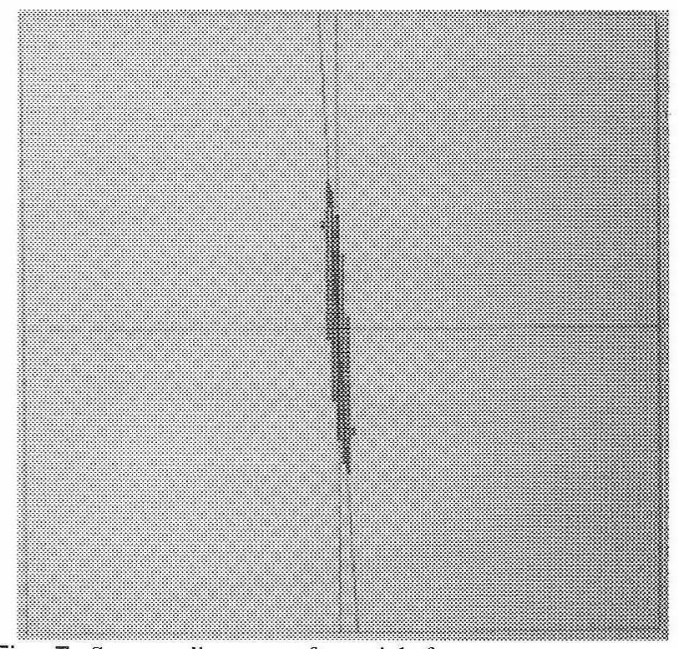

Fig. -7 Scatter diagram of spatial frequency components after Fourier-transformation of image in Fig. -5 , and inclination $\left(\theta_{1}\right)$ of the long axis.

とになる。そこで， $\mathrm{t}_{2}$ 時点の『しわマップ』を反 時計回りに 4.6 度回転させ，回転ず机の補正を行 う。回転前の座標点 $\left(x^{\prime}, y^{\prime}\right)$ に対して， $\theta$ だけ 回転した後の座標点 ( $x, y)$ は, 式(9), 式(10)で求 めた。

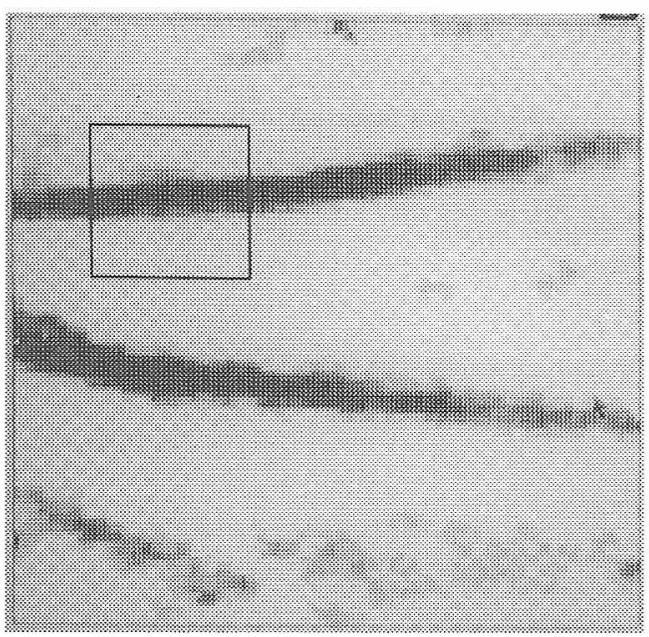

Fig.-9 "Wrinkle map" after reconstruction using constant pitch of data obtained at time $t_{1}$.

$\mathrm{x}=\mathrm{x}^{\prime} \cos \theta+\mathrm{y}^{\prime} \sin \theta \quad$ (9) $\mathrm{y}=-\mathrm{x}^{\prime} \sin \theta+\mathrm{y}^{\prime} \cos \theta \quad$ (10) 次いで， $\mathrm{t}_{1}$ 時点の『しわマップ』デー夕，回転 後の $\mathbf{t}_{2}$ 時点の『しわマップ』データについて, 等ピッチ化を行った。結果を Fig.-9, Fig.-10に 示す。

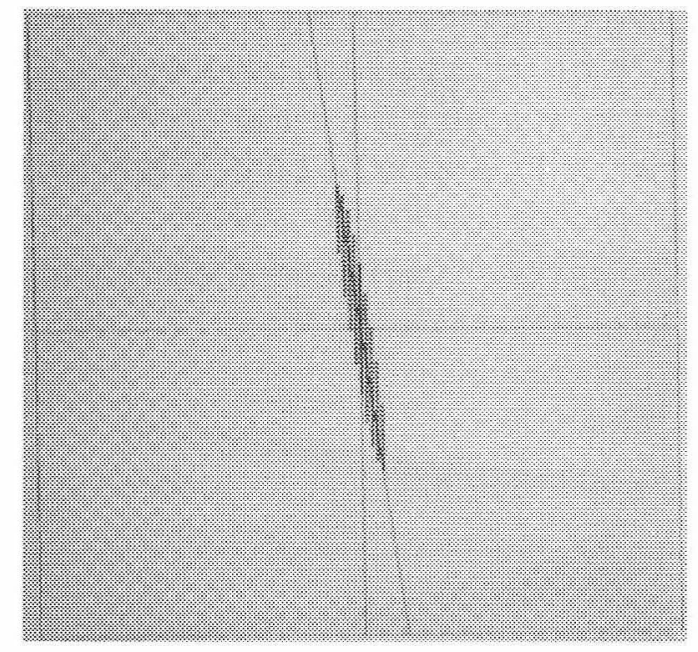

Fig.-8 Scatter diagram of spatial frequency components after Fourier-transformation of image in Fig.-6, and inclination $\left(\mathrm{O}_{2}\right)$ of the long axis.

Fig.-9には，テンプレートマッチングのため に指定した小領域を四角で囲い, 左上に示す。Fig. -11には，2.2に記した方法で得られた相関係数 を図示した。結果として, Fig.-11左上の○印の

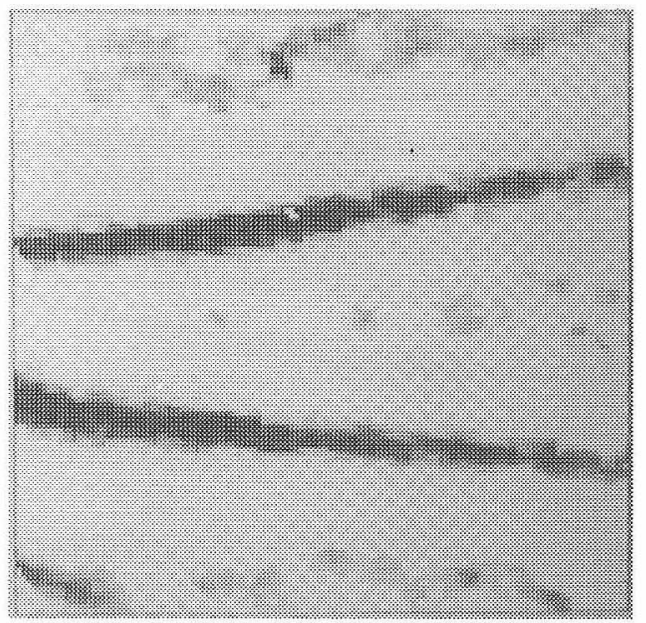

Fig.-10 "Wrinkle map" after correcting rotation shift of data obtained at time $t_{2}$ and then reconstructing using constant pitch.

位置にテンプレートの左上隅が位置する時, 算出 した相関係数は最大の正の值 $(\mathrm{r}=0.80)$ をとり, この位置が最適な位置合わせ位置と推定された。 この結果をもとに, 等ピッチ化後の【しわマップ】 の X，Y方向のずれを補正したものをFig.-12, 


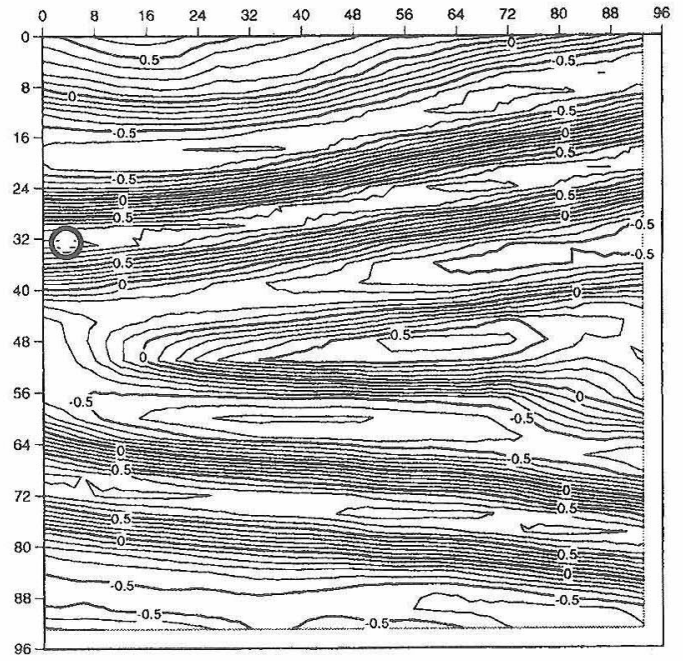

Fig.-11 Correlation coefficient as a parameter that indicates degree of position matching in template matching process.

(Correlation coefficient at the point circled; maximum $\mathrm{r}=0.80$ )

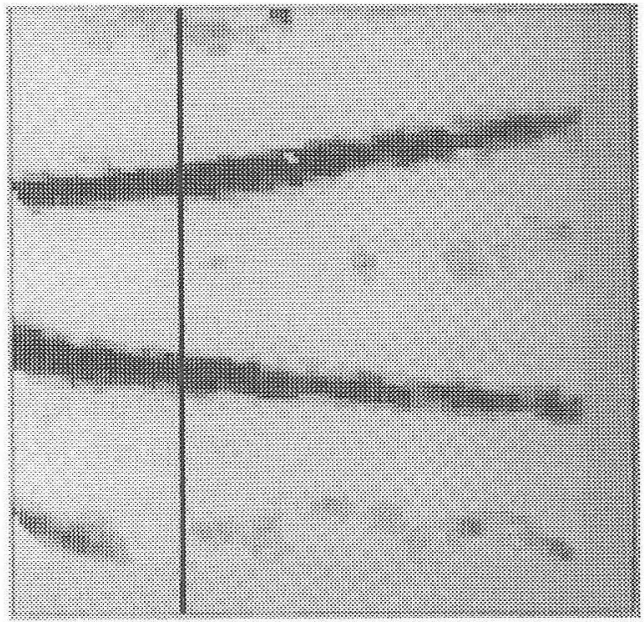

Fig.-12 "Wrinkle map" after positioning of data obtained at time $\mathrm{t}_{1}$.

Fig.-13 に示す。

この実施例で用いた $\mathrm{t}_{1}, \mathrm{t}_{2}$ 時点のしわレプリカ 計測デー夕間には，基本的に拡大・縮小・ひずみ は，生じていないはずである。そこで，Fig.-12 とFig.-13の全域の格子点の対のデータ, $128 \times$ 128 を対象としてしわの深さの差の総平均値と, その標準偏差を求め, 今回構築した位置合わせシ ステムにおける位置合わせの精度の目安とする。

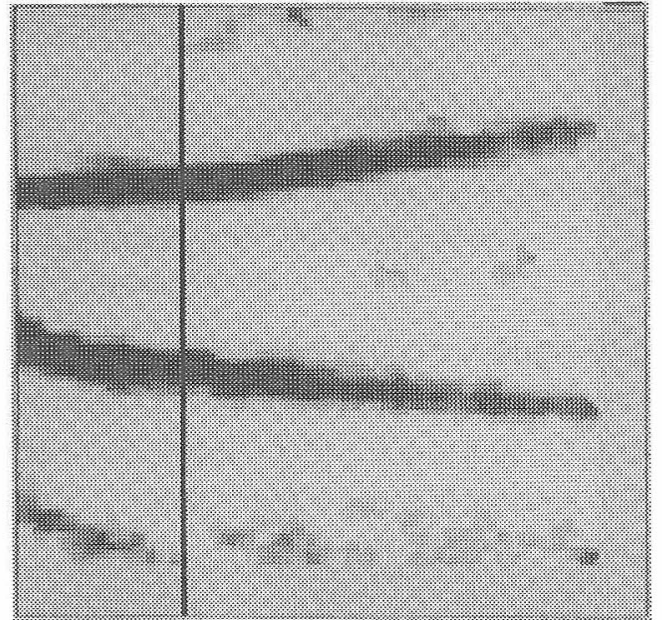

Fig.-13 "Wrinkle map" after positioning of data obtained at time $\mathrm{t}_{2}$.

結果として，しわの深さの差の総平均值は，そ の期待值 $\pm 0 \mu \mathrm{m}$ に対して，実測值は $1.2 \mu \mathrm{m}$ で あり，その標準偏差は $24.3 \mu \mathrm{m}$ であった。Fig.-12 とFig.-13に示した縦線の位置の樑さ方向の断 面図を，それぞれ実線と点線を用いて，Fig.-14 に示す。

上記した実施例では， $\mathrm{t}_{1}, \mathrm{t}_{2}$ 時点で形状変化が ないものを対象としているが，実際に同一被験者 
のしわ形状を $\mathrm{t}_{1}, \mathrm{t}_{2}$ 時点で計測した場合, 縦横 $12.5 \mathrm{~mm} \times 15 \mathrm{~mm}$ 相当の計測領域内に観測される 個々のしわは，形状变化のみならず，そのしわ間 隔も当然变化している。従って，比較・照合領域
しわを含む小領域に限定すると共に，回転ずれの 大きさを $\mathrm{t}_{1}, \mathrm{t}_{2}$ 時点の『しわマップ』データのフ 一リ工变換後の空間周波数付置の長軸の角度差か ら推定・補正した。また $\mathrm{t}_{1}$ 時点の『しわマップ』

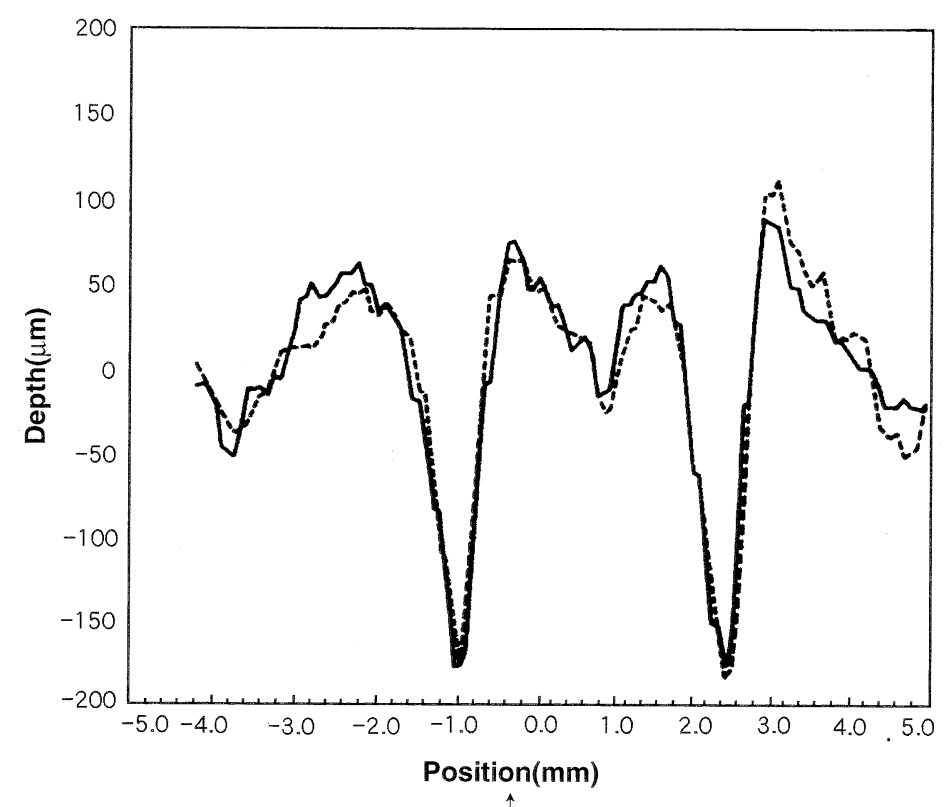

Fig.-14 Cross-sectional images of depth at vertical line shown in Figs. -12 and -13 .

$\left(\right.$ Solid line $=$ data at time $t_{1} ;$ Dotted line $=$ data at time $t_{2}$ )

とした小領域内では位置合わせができているが, その他の領域では，位置ずれが生じているのが普 通である。実用にあたっては，比較したい小領域 内でのみ形状変化をデー夕化する事とし, 当該領 域以外のしわ形状変化を見る時は, 再度領域指定 をやり直し, 回転ずれの補正, X, Y 方向の補正, そしてテンプレートマッチングを行いその後形状 変化のデー夕化を実施している。

\section{4. ま と}

$\mathrm{t}_{1}, \mathrm{t}_{2}$ なる時間軸上の, 異なる時点で計測した しわの 3 次元形状計測デー夕は, その計測領域 が一致していないのが普通であり， $\mathrm{t}_{1}$ と $\mathrm{t}_{2}$ 時点 間で発生したしわ形状変化をデータ化することは できない。

著者らは，位置合わせ領域を比較・照合したい
と, 回転ずれ補正後の $\mathrm{t}_{2}$ 時点の『しわマップ』 の中心領域を対象に等ピッチ化 $(80 \mu \mathrm{m}$ 間隔, $128 \times 128$ 格子点）を行い，正確な位置合わせの ための格子点デー夕を再構築した。次いで, 比較 したいしわの小領域を指定し，テンプレートマッ チングを行うことによって，X，Y 方向のずれを 補正することを試みたところ，実用にたえる位置 合わせ結果をうることができた。

\section{参 考文 献}

1）川口由起子, 金子治, 小松原良平, 吉澤 徹, 粧技誌，28，2，153-162，(1994）

2) コンピュー夕画像処理: 応用実践編 3, 総研出 版 (1992), 4-27

3) 尾上守夫, 前田紀彦, 斉藤 優, 情報処理, 17, 7, 634-640, (1976) 
4) S. T. Barnard and W. B. Thompson, IEEE Trans. Pattern Analysis and Machine Intelligence, PAMI$2,4,333-340,(1980)$
5）津田雄則，長谷川孝明，第 5 回「外観検査の自 動化」ワークショップ 43-48, 1993

6 ）多変量解析法：日科技連 (1971)，176-181

\title{
Pattern Matching of Translated and Rotated 3-D Images of Wrinkles
}

\author{
Osamu Kaneko $\dagger^{2,}$ Masami Wake $\dagger^{2}$ \\ Yukiko Kawaguchi $\dagger^{2}$ and Ryohei Komatsubara $\dagger^{3}$ \\ Institute of Beauty Sciences, Shiseido Ltd. $\dagger^{2}$ \\ TechnoArts Laboratory $\dagger^{3}$
}

The authors have developed an instrument for instantaneous, non-contact measurement of the threedimensional morphology of wrinkles on human skin to determine transient changes in the shape of wrinkles and changes in the skin surface microtopography after application of an anti-wrinkle agent. When such measurements are made, it is usually impossible to record shape changes accurately over time unless the geometrical position of the target skin region is precisely defined. Generally, when measuring wrinkle shapes in the same individual at different times, it is difficult to locate exactly the same target skin region at every measurement session, even with the greatest of attention. As a result, image dislocations can occur. Such dislocations are caused when the region to be measured is shifted relative to the $\mathrm{X}-/ \mathrm{Y}$-axes of the observation system, or when the region is rotated, enlarged, reduced or subjected to local distortion caused by any of a variety of uncontrollable factors. It is impossible to define markers at multiple positions in the target region to aid in the repositioning of the observation system. Consequently, it is difficult to correct for any enlargement, reduction and/or distortion that might have occurred in the target region.

By limiting the target region to a small area with wrinkles to which comparison and reference can be made, the authors developed a technique for correcting rotation and/or dislocation errors. We also introduce a new method in order to compare and reference the changes in wrinkle shapes observed in measurements made at different times. 